\title{
Fire Incidents Involving Sleepwear Worn by Children Ages 6-12
}

QC 100 .45753 no. 810

1973

c. 2

U.S. EPARTMENT OF COMMERCE National Bureau of

Standards 
The National Bureau of Standards ${ }^{1}$ was established by an act of Congress March 3, 1901. The Bureau's overall goal is to strengthen and advance the Nation's science and technology and facilitate their effective application for public benefit. To this end, the Bureau conducts research and provides: (I) a basis for the Nation's physical measurement system, (2) scientific and technological services for industry and government, (3) a technical basis for equity in trade, and (4) technical services to promote public safety. The Bureau consists of the Institute for Basic Standards, the Institute for Materials Research, the Institute for Applied Technology, the Institute for Computer Sciences and Technology, and the Office for Information Programs.

THE INSTITUTE FOR BASIC STANDARDS provides the central basis within the United States of a complete and consistent system of physical measurement; coordinates that system with measurement systems of other nations; and furnishes essential services leading to accurate and uniform physical measurements throughout the Nation's scientific community, industry, and commerce. The Institute consists of a Center for Radiation Research, an Office of Measurement Services and the following divisions:

Applied Mathematics - Electricity - Mechanics - Heat - Optical Physics - Nuclear Sciences ${ }^{2}$ - Applied Radiation ${ }^{2}$ - Quantum Electronics ${ }^{3}$ - Electromagnetics ${ }^{3}$ - Time and Frequency ${ }^{3}$ - Laboratory Astrophysics ${ }^{3}$ - Cryogenics ${ }^{3}$.

THE INSTITUTE FOR MATERIALS RESEARCH conducts materials research leading to improved methods of measurement, standards, and data on the properties of well-characterized materials needed by industry, commerce, educational institutions, and Government; provides advisory and research services to other Government agencies; and develops, produces, and distributes standard reference materials. The Institute consists of the Office of Standard Reference Materials and the following divisions:

Analytical Chemistry — Polymers - Metallurgy — Inorganic Materials - Reactor Radiation - Physical Chemistry.

THE INSTITUTE FOR APPLIED TECHNOLOGY provides technical services to promote the use of available technology and to facilitate technological innovation in industry and Government; cooperates with public and private organizations leading to the development of technological standards (including mandatory safety standards), codes and methods of test; and provides technical advice and services to Government agencies upon request. The Institute consists of a Center for Building Technology and the following divisions and offices:

Engineering and Product Standards - Weights and Measures - Invention and Innovation - Product Evaluation Technology - Electronic Technology — Technical Analysis

- Measurement Engineering - Structures, Materials, and Life Safety ${ }^{*}$ - Building

Environment ${ }^{4}$ - Technical Evaluation and Application ${ }^{4}$ - Fire Technology.

THE INSTITUTE FOR COMPUTER SCIENCES AND TECHNOLOGY conducts research and provides technical services designed to aid Government agencies in improving cost effectiveness in the conduct of their programs through the selection, acquisition, and effective utilization of automatic data processing equipment; and serves as the principal focus within the executive branch for the development of Federal standards for automatic data processing equipment, techniques, and computer languages. The Institute consists of the following divisions:

Computer Services - Systems and Software - Computer Systems Engineering -- Information Technology.

THE OFFICE FOR INFORMATION PROGRAMS promotes optimum dissemination and accessibility of scientific information generated within NBS and other agencies of the Federal Government; promotes the development of the National Standard Reference Data System and a system of information analysis centers dealing with the broader aspects of the National Measurement System; provides appropriate services to ensure that the NBS staff has optimum accessibility to the scientific information of the world. The Office consists of the following organizational units:

Office of Standard Reference Data - Office of Information Activities - Office of Technical Publications - Library - Office of International Relations.

\footnotetext{
1 Headquarters and Laboratories at Gaithersburg, Maryland, unless otherwise noted; mailing address Washington, D.C. 20234.

2 Part of the Center for Radiation Research.

${ }^{3}$ Located at Boulder, Colorado 80302.

- Part of the Center for Building Technology.
} 


\section{Fire Incidents Involving Sleepwear Worn by Children Ages 6-12}

James A. Slater

Fire Technology Division Institute for Applied Technology

National Bureau of Standards

Washington, D.C. 20234

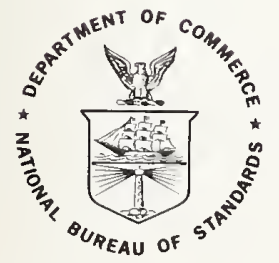

U.S. DEPARTMENT OF COMMERCE, Frederick B. Dent, Secretary NATIONAL BUREAU OF STANDARDS, Richard W. Roberts, Director Issued December 1973 
National Bureau of Standards Technical Note 810

Nat. Bur. Stand. (U.S.), Tech. Note 810, 23 pages (Dec. 1973)

CODEN: NBTNAE 
This report is a revision of an unpublished document that was used as supporting evidence by the Secretary of Commerce in determining the need for a flammability standard for children's sleepwear sizes 7 through 14. A "Notice of Finding that Flammability Standard May Be Needed and Institution of Proceedings" was published in the Federal Register on June 15, 1972 (vol. 37, no. 116, pp. 11896-11897). A finding of need and a proposed flammability standard for children's sleepwear (sizes 7-14) was subsequently published in the Federal Register on March 12, 1973 (vol. 38, no. 47, pp. 6700-6710). The conclusions and recommendations contained in this report were used as part of the basis for the finding of need and thus represent views prior to publication of the proposed standard. 

CONTENTS

Page

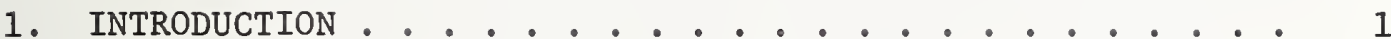

2. THE FLAMMABLE FABRICS ACCIDENT CASE AND TESTING SYSTEM . . . . . . . . . . . . . . 2

3. FINDINGS FROM FFACTS ................ 3

3.1 General Involvement of Sleepwear. . . . . . . . . 3

3.2 Age and Sex of Persons Involved in Sleepwear Incidents . . . . . . . . . . . . . 4

3.3 Ignition of Sleepwear For Ages 6-12 . . . . . . 6

3.4 Extent of Injury For the 6-12 Age Group . . . . . . 7

3.5 Fabric Analysis ............. 9

4. FINDINGS FROM OTHER SOURCES. . . . . . . . . . . 10

5. CONCLUSIONS. . . . . . . . . . . . . 12

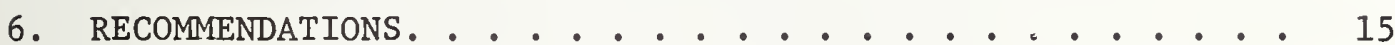

7. GLOSSARY . . . . . . . . . . . 15

8. REFERENCES .................... 16 



\section{FIRE INCIDENTS INVOLVING SLEEPWEAR WORN BY CHILDREN AGES 6-12}

\section{James A. Slater}

Sleepwear was the first fabric item ignited more frequently than any other item in over 1,900 fire incidents reported to the National Bureau of Standards Flammable Fabrics Accident Case and Testing System (FFACTS). Information acquired since promulgation of the current sleepwear flammability standard protecting children of ages 0-5 indicates a problem of comparable magnitude exists for children of ages 6-12. Of 316 incidents involving non-contaminated sleepwear that was first to ignite, about one-fourth involved children 0-5 years old and one-fourth involved children 6-12 years old. For the 6-12 group, sleepwear ignited first more often than all other garment items combined. Females outnumbered males 4-to-1 in the 6-12 group, due mostly to the involvement of nightgowns and kitchen ranges, the most common ignition source for this age group. Five of the 6-12 year old children died and 52 of 74 victims were hospitalized. Almost all of the first-to-ignite sleepwear in this group was cotton. Data from Shriners Burns Institute and the National Burn Information Exchange provide further evidence of the involvement of children ages 6-12 in garment fires. It is recommended that a new standard be issued covering sleepwear sizes 7 through 14 to effectively protect 6-12 year old children.

Key words: Accidents; burns; children; clothing fires; deaths; FFACTS; fire; flammable fabrics; injury; sleepwear; standards; statistics.

\section{INTRODUCTION}

The current mandatory standard [1] ${ }^{1}$ for the flammability of children's sleepwear ${ }^{2}$ applies to sleepwear sizes 0 through $6 \mathrm{X}$. This standard is intended "to provide a high and effective level of protection to children approximately 5 years of age and younger against unreasonable risk of death or injury suffered as a result of ignition and continued burning of sleepwear garments, as defined in the standard, and/or as a result of the continued burning of molten or other material falling or dripping from the burning garments." The finding of need for the standard was based, in part, on information from the Flammable Fabrics Accident Case and Testing System (FFACTS) at the National Bureau of Standards (NBS).

\footnotetext{
${ }^{1}$ Figures in brackets indicate the literature references at the end of this paper.

2 Definitions of "sleepwear" and other italicized terms used in this report are given in the glossary at the end of the report.
} 
Since the standard was promulgated, the FFACTS data base has increased from 580 cases in November 1971 to 1,964 cases as of December 1972. In the current data base, children under age 6 continue to be the most highly represented age group involved in sleepwear incidents. However, children of ages 6 through 12 were involved nearly as frequently as children in the $0-5$ age group in fires involving sleepwear items. As a result, a finding of possible need for a flammability standard, covering sleepwear normally worn by children of ages 6-12 was issued by the Secretary of Commerce on June 15, 1972 [2]. The following is a summary and analysis of data from FFACTS and from outside sources on the involvement of children ages 612 in sleepwear-related fires.

\section{THE FLAMMABLE FABRICS ACCIDENT CASE AND TESTING SYSTEM}

Section $14(a)$ of the Flammable Fabrics Act, ${ }^{1}$ as revised and amended December 14, 1967 [3], states that the Secretary of Health, Education, and Welfare in cooperation with the Secretary of Commerce shall conduct a continuing investigation of deaths, injuries and economic losses resulting from accidental burning of fabric products. The primary sources of information on accidental fires involving fabric products are state and local fire departments, voluntary public safety-oriented organizations, and Federal agencies such as the Food and Drug Administration (FDA) which send reports of these incidents along with the remains of fabric products involved to the Fire Technology Division of the National Bureau of Standards for analysis and testing. These reported incidents are not selected on a statistical basis and they do not, therefore, constitute a statistically representative sample of all fabric fire incidents in the United States. Nevertheless, they represent events investigated without known preference and may be roughly representative of incidents reported to the agencies from which the FDA and others obtain accident data.

Processing of the reports and fabric samples received by NBS includes reviewing and screening of incident reports, laboratory testing and characterization of fabric products involved, data encoding, formatting, editing, and entry into a computer master file. Some 200 different data elements can be coded for an incident.

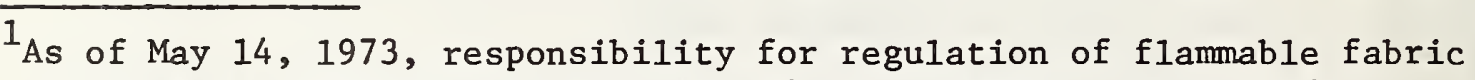
products is under the jurisdiction of the Consumer Product Safety Commission. However, this report was researched prior to May 14 and thus the work being reported was done under the authority given to the Department of Commerce in the Flammable Fabrics Act [3].
} 


\subsection{General Involvement of Sleepwear}

Sleepwear items were ignited in 413 fire incidents reported to NBS as a part of the 1,964 cases processed in FFACTS to date. Included in the general category of sleepwear are pajamas, nightgowns, robes and any other garments related specifically to sleeping. A total of 485 separate items of sleepwear were involved in the 413 incidents reported to have involved sleepwear. Table 1 shows the distribution of specific fabric products that were first to ignite in

Table 1. Distribution of Fabric Product Incidents in FFACTS For Fabric Items First to Ignite

(Includes Items Contaminated With Flammable Liquids)

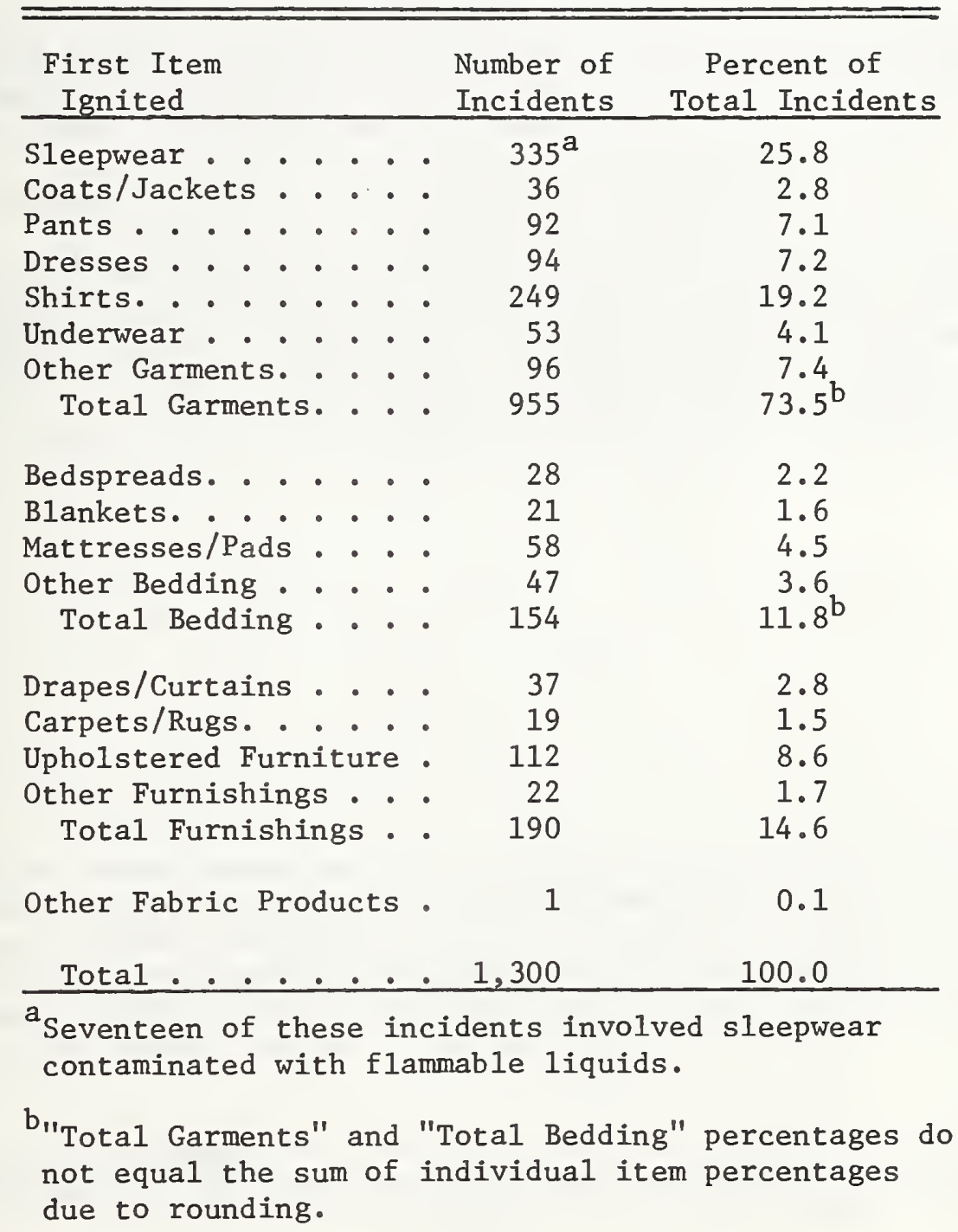


FFACTS incidents (including those items contominated with flammable liquids). Sleepwear items were first to ignite more frequently than any other fabric product in the data base. 1 The 335 sleepwear incidents represent 35 percent of the total garments first to ignite and 26 percent of all fabric products that were ignited first.

Twenty-two of the 413 sleepwear incidents involved flammable liquid contamination or probable contamination.2 (Seventeen of the 22 were incidents in which sleepwear ignited first.) Since only a small percentage of sleepwear ignitions involved flammable liquids and flammable liquid obscures the ignition hazard of the fabric product itself, sleepwear contaminated with flammable liquids will be excluded from the remainder of this report.

\subsection{Age and Sex of Persons Involved in Sleepwear Incidents}

Table 2 shows the age distribution and sex of persons involved in FFACTS sleepwear incidents in which no flammable liquid contamination occurred. In 318 of the incidents, sleepwear was the first item ignited. The 6-12 age group, in particular, was involved in 77 (24 percent) of the 316 incidents in which uncontaminated sleepwear ignited first (and for which the victim's age was known) and represented 79 (20 percent) of the 389 persons involved in all sleepwear incidents. In the 6-12 group, females were involved almost four times as frequently as males in sleepwear accidents; this differs from the more equal representation of males and females in the 0-5 age group, but it is typical of all the older age groups.

$\overline{1_{\text {Prior to }} \text { late } 1970}$, FDA investigators concentrated almost exclusively on garment fires, resulting in garments being somewhat overrepresented in the FFACTS data. Since that time, however, all fabric fires have been investigated regardless of the type of fabric item involved, and enough non-garment data have been collected to firmly establish patterns of fabric item involvement for the most common ignition sources.

${ }^{2}$ In 12 cases sleepwear items were definitely contaminated while in 10 other cases, contamination was likely but could not be definitely established from reports of the incidents. 
Table 2. Age Distribution and Sex of Persons Involved in Sleepwear Incidents ${ }^{a}$

\begin{tabular}{|c|c|c|c|c|c|c|}
\hline \multirow[t]{2}{*}{ Age } & \multicolumn{3}{|c|}{ Al1 Sleepwear Incidents } & \multicolumn{3}{|c|}{$\begin{array}{c}\text { First-to-Ignite } \\
\text { Sleepwear Incidents }\end{array}$} \\
\hline & Male & Female & Total & Male & Female & Total \\
\hline . . . & 40 & 54 & 94 & 36 & 50 & 86 \\
\hline $6-12 . \cdot \cdot \cdot$ & 18 & 61 & 79 & 16 & 61 & 77 \\
\hline $13-20$. . . & 4 & 12 & 16 & 4 & 11 & 15 \\
\hline $21-45 . .$. & 8 & 49 & 57 & 4 & 38 & 42 \\
\hline 46-65.... & 9 & 61 & 70 & 6 & 41 & 47 \\
\hline $66+. \cdot \cdot \cdot$ & 14 & 59 & 73 & 9 & 40 & 49 \\
\hline Total Known & 93 & 296 & 389 & 75 & 241 & 316 \\
\hline Unknown. . & - & 2 & 2 & - & 2 & 2 \\
\hline Total. . & 93 & 298 & 391 & 75 & 243 & 318 \\
\hline
\end{tabular}

a 22 incidents involving sleepwear items contaminated with flammable liquids have been excluded; 17 of the 22 were

"first-to-ignite sleepwear incidents".

Table 3 compares the age distribution of persons involved in FFACTS sleepwear incidents, persons involved in all FFACTS incidents, and the United States as a whole. Only those incidents in which the fabric item was first to ignite are considered in the table and all contaminated items have been excluded, as in table 2. The total number of persons involved in sleepwear ignitions and in all FFACTS ignitions (with the above qualifications), on which the percentages in table 3 are based, are 316 and 1,023 , respectively.

The 6-12 group represents 15 percent of the FFACTS data base and 14 percent of the U.S. population, yet 24 percent of the persons involved in first-to-ignite sleepwear incidents were in this age bracket. Considering that 14 percent of the U.S. population is between ages 6 and 12, one might expect 14 percent, or 44, of the 316 incidents where sleepwear ignited first to involve children 6-12; however, 6-12 year olds in the FFACTS data base were involved in 77 incidents in which sleepwear ignited first, or 1.8 times as frequently as expected. Females were much more frequently involved in these incidents than males. The percentage of females 6-12 years old involved in sleepwear incidents is 1.9 times greater than their overall representation in the FFACTS data base and 2.7 times their representation in the total U.S. population. 


\section{Table 3. Age Distributions and Sex of Persons Involved in FFACTS Sleepwear Incidents, in All FFACTS \\ Incidents and in the U.S. Population}

\begin{tabular}{|c|c|c|c|c|c|c|c|c|c|}
\hline \multirow{3}{*}{ Age } & \multicolumn{6}{|c|}{ Persons Involved, as $\%$ of the Total ${ }^{a}$} & \multirow{2}{*}{\multicolumn{3}{|c|}{$\begin{array}{l}\text { Percent of Total } \\
\text { U.S. Population }\end{array}$}} \\
\hline & \multicolumn{3}{|c|}{ Sleepwear } & \multicolumn{3}{|c|}{ A11 FFACTS } & & & \\
\hline & Female & Male & Total & Female & Male & Total & Female & Male & Total \\
\hline $0-5$ & 16 & 11 & 27 & 11 & 10 & 21 & 5 & 5 & 10 \\
\hline $6-12$ & 19 & 5 & 24 & 10 & 5 & 15 & 7 & 7 & 14 \\
\hline $13-20$ & 3 & 1 & $5^{c}$ & 3 & 4 & 7 & 8 & 8 & 16 \\
\hline $21-45$. & 12 & 1 & 13 & 13 & 12 & 25 & 16 & 15 & 31 \\
\hline 46-65. & 13 & 2 & 15 & 9 & 8 & 17 & 10 & 9 & 19 \\
\hline $66+$ & 13 & 3 & 16 & 10 & 5 & 15 & 6 & 4 & 10 \\
\hline Total. & 76 & 24 & 100 & 56 & 44 & 100 & 52 & 48 & 100 \\
\hline
\end{tabular}

${ }^{a}$ For incidents in which a fabric item involved was the first item ignited and was not contaminated by flammable liquids.

berived from 1970 U.S. Bureau of the Census population statistics [4].

${ }^{c}$ Percentages were computed independently and therefore total percentages may not equal the sum of individual percentages.

\subsection{Ignition of Sleepwear For Ages 6-12}

Sleepwear was the first item ignited more of ten than all other garments combined in incidents involving the 6-12 age group (55 percent of the garments first to ignite). Table 4 shows these garment data and the particular ignition sources involved. Ignitions of sleepwear outnumbered by 4-to-1 the ignitions of any other single apparel item for persons in the 6-12 age group. Kitchen range ignitions of sleepwear stand out as the most common type of garment ignition in this age group.

A further breakdown of the sleepwear items is given in table 5 . of the 77 sleepwear items ignited first in incidents involving 6-12 year olds, 40 were pajamas, 31 were nightgowns and 6 were robes. Females accounted for 32 of 38 kitchen range ignitions of sleepwear; two-thirds of the 32 involved pajamas and one-third nightgowns. In 12 incidents initiated by heaters or furnaces, nightgowns were ignited first 9 times and 10 of the 12 persons involved were females. 
Table 4. Ignition Sources For First-to-Ignite Garment Items ${ }^{a}$ For the 6-12 Age Group

\begin{tabular}{|c|c|c|c|c|c|c|c|c|c|}
\hline \multirow{2}{*}{$\begin{array}{l}\text { Ignition } \\
\text { Source }\end{array}$} & \multicolumn{9}{|c|}{ First Item Ignited } \\
\hline & $\begin{array}{c}\text { Sleep- } \\
\text { wear } \\
\end{array}$ & $\begin{array}{l}\text { Coats } / \\
\text { Jackets } \\
\end{array}$ & Pants & Dresses & Shirts & \begin{tabular}{|c|} 
Sweaters \\
Sweatshirts \\
\end{tabular} & \begin{tabular}{|c|} 
Under- \\
wear
\end{tabular} & Other & Tota I \\
\hline $\begin{array}{l}\text { Kitchen } \\
\text { Range. } \\
\text { Match/ }\end{array}$ & 38 & 1 & - & 7 & 10 & - & - & - & 56 \\
\hline $\begin{array}{l}\text { Lighter. } \\
\text { Heater/ }\end{array}$ & 13 & - & 4 & 4 & 5 & - & 6 & 2 & 34 \\
\hline $\begin{array}{l}\text { Furnace. } \\
\text { Open Fire } \\
\text { Candle/ }\end{array}$ & $\begin{array}{r}12 \\
9\end{array}$ & - & $\overline{3}$ & $\begin{array}{l}5 \\
-\end{array}$ & $\begin{array}{l}1 \\
1\end{array}$ & $\overline{1}$ & $\overline{2}$ & - & $\begin{array}{l}18 \\
16\end{array}$ \\
\hline $\begin{array}{l}\text { Lantern. } \\
\text { other }\end{array}$ & $\begin{array}{l}5 \\
-\end{array}$ & $\begin{array}{l}1 \\
-\end{array}$ & - & $\overline{4}$ & - & $\overline{1}$ & $\begin{array}{l}1 \\
1\end{array}$ & $\begin{array}{l}2 \\
1\end{array}$ & $\begin{array}{l}9 \\
8\end{array}$ \\
\hline Total. & 77 & 2 & 7 & 20 & 18 & 2 & 10 & 5 & 141 \\
\hline
\end{tabular}

Table 5. Ignition Sources For Specific First-to-Ignite Sleepwear Items For the 6-12 Age Group

\begin{tabular}{|c|c|c|c|c|c|c|c|}
\hline \multirow{2}{*}{$\begin{array}{l}\text { Ignition } \\
\text { Source }\end{array}$} & \multicolumn{7}{|c|}{ First Item Ignited } \\
\hline & $\begin{array}{r}\mathrm{Pa} \\
\mathrm{Male} \\
\end{array}$ & $\begin{array}{l}\text { jamas } \\
\text { Female }\end{array}$ & $\begin{array}{l}\text { Nigh } \\
\text { Male }\end{array}$ & $\begin{array}{l}\text { Eowns } \\
\text { Female }\end{array}$ & $\begin{array}{r}\mathrm{R} \\
\mathrm{Male} \\
\end{array}$ & $\begin{array}{l}\text { Female } \\
\text { Female }\end{array}$ & $\begin{array}{c}\text { Al1 } \\
\text { Sleepwear } \\
\end{array}$ \\
\hline Kitchen Range. & 5 & 22 & - & 9 & 1 & 1 & 38 \\
\hline Match/Lighter. & 4 & 1 & - & 6 & - & 2 & 13 \\
\hline Heater/Furnace & 2 & 1 & - & 9 & - & - & 12 \\
\hline Open Fire. . . & 1 & 1 & 1 & 5 & 1 & - & 9 \\
\hline Candle/Lantern & 1 & 2 & - & 1 & - & 1 & 5 \\
\hline Total. . . & 13 & 27 & 1 & 30 & 2 & 4 & 77 \\
\hline
\end{tabular}

\subsection{Extent of Injury For the 6-12 Age Group}

Table 6 shows the disposition of persons 6-12 years old involved in garment fires and the fabric item that was ignited first in each incident. Fifty-two of 74 victims (whose disposition was known) of sleepwear ignitions required hospitalization while 5 other victims died from injuries sustained during these incidents.

For those garments that were not contaminated with flammable liquids and were first to ignite, the percent of body area burned due to the garments is given in table 7 for victims of these incidents. 
Twenty-seven of 74 victims of sleepwear ignitions with known burn injuries had 11-30 percent body burns attributable to the sleepwear. Seventeen of the 74 victims had over 30 percent body burns due to sleepwear ignition.

Table 6. Injury Disposition of Persons in the 6-12 Age Group by Garment Itema First to Ignite

\begin{tabular}{|c|c|c|c|c|c|c|}
\hline $\begin{array}{l}\text { First Item } \\
\text { Ignited }\end{array}$ & $\begin{array}{c}\text { No } \\
\text { Injury }\end{array}$ & $\begin{array}{c}\text { First Aid/ } \\
\text { Treated } \\
\& \text { Released } \\
\end{array}$ & $\begin{array}{c}\text { Hospital- } \\
\text { ized }\end{array}$ & Died & $\begin{array}{c}\text { Un- } \\
\text { Known } \\
\end{array}$ & $\begin{array}{c}\text { Total } \\
\text { Persons } \\
\text { Involved } \\
\end{array}$ \\
\hline Sleepwear. . & - & 17 & 52 & 5 & 3 & 77 \\
\hline Coats/Jackets. & 1 & - & 1 & - & - & 2 \\
\hline Pants. . . . & - & 5 & 3 & - & - & 8 \\
\hline Dresses. • • & - & 4 & 15 & 1 & - & 20 \\
\hline Shirts • • • & - & 10 & 6 & - & 3 & 19 \\
\hline $\begin{array}{l}\text { Sweaters/ } \\
\text { Sweatshirts }\end{array}$ & - & 2 & - & - & - & 2 \\
\hline Underwear. . & - & 3 & 7 & - & - & 10 \\
\hline Other. . . & - & 1 & 4 & - & - & 5 \\
\hline Total.... & 1 & 42 & 88 & 6 & 6 & 143 \\
\hline
\end{tabular}

atems contaminated with flammable liquids are excluded.

Table 7. Total Body Area Burned For Persons in the 6-12 Age Group by Garment Item ${ }^{a}$ First to Ignite

\begin{tabular}{|c|c|c|c|c|c|c|c|}
\hline \multirow{2}{*}{$\begin{array}{l}\text { First Item } \\
\text { Ignited }\end{array}$} & \multicolumn{6}{|c|}{ Total Body Area Burned } & \multirow{2}{*}{$\begin{array}{l}\text { Total } \\
\text { Persons } \\
\text { Involved }\end{array}$} \\
\hline & \begin{tabular}{|c|} 
No \\
Burn \\
\end{tabular} & $1-10 \%$ & $11-30 \%$ & $31-60 \%$ & $\begin{array}{r}\text { Over } \\
60 \% \\
\end{array}$ & $\begin{array}{c}\text { Un- } \\
\text { known }\end{array}$ & \\
\hline Sleepwear. . & - & 30 & 27 & 12 & 5 & 3 & 77 \\
\hline Coats/Jackets. & 1 & - & 1 & - & - & - & 2 \\
\hline Pants. . . . & - & 6 & - & 1 & - & 1 & 8 \\
\hline Dresses. . . & - & 7 & 9 & 2 & 1 & 1 & 20 \\
\hline Shirts . . . & - & 10 & 6 & - & - & 3 & 19 \\
\hline $\begin{array}{l}\text { Sweaters/ } \\
\text { Sweatshirts }\end{array}$ & - & 2 & - & - & - & - & 2 \\
\hline Underwear. & - & 3 & 6 & - & - & 1 & 10 \\
\hline Other. . . & - & 3 & 2 & - & - & - & 5 \\
\hline Total... & 1 & 61 & 51 & 15 & 6 & 9 & 143 \\
\hline
\end{tabular}


Of the 77 first-to-ignite sleepwear items, fabric remnants of 31 of the pajamas, 22 of the nightgowns and 5 of the robes were tested at NBS. The outer layer fiber content and surface construction of these garments are given in table 8 along with the "reported" fiber content and construction of the 19 sleepwear items for which no remnants were available for testing.

Table 8. Fiber Content and Outer Layer Surface Construction of First-to-Ignite Sleepwear Items ${ }^{a}$ For the 6-12 Age Group

\begin{tabular}{|c|c|c|c|c|c|c|}
\hline \multirow{2}{*}{$\begin{array}{c}\text { Outer Layer } \\
\text { Fiber Construction }\end{array}$} & \multicolumn{2}{|c|}{ Pajamas } & \multicolumn{2}{|c|}{ Nightgowns } & \multicolumn{2}{|c|}{ Robes $^{\mathrm{b}}$} \\
\hline & Tested & Reported & Tested & Reported & Tested & Reported \\
\hline Cotton/Flanne1 ${ }^{c}$. . & 22 & 2 & 17 & 6 & 1 & - \\
\hline Cotton/Plain . . & 7 & - & 4 & - & 2 & - \\
\hline Cotton/Knit. . . . & 1 & - & - & - & - & - \\
\hline Cotton/Terrycloth. . & - & - & - & - & 1 & - \\
\hline Cotton/Unknown . . & - & 3 & - & 3 & - & 1 \\
\hline Acetate/Knit . . & - & - & - & - & 1 & - \\
\hline Rayon-Cotton/Flannel & 1 & - & - & - & - & - \\
\hline Acetate-Nylon/Knit . & - & - & 1 & - & - & - \\
\hline Total known. : . . & 31 & 5 & 22 & 9 & 5 & 1 \\
\hline Unknown. . . . . . & - & 4 & - & - & - & - \\
\hline Total..... & 31 & 9 & 22 & 9 & 5 & 1 \\
\hline
\end{tabular}

a Fabrics presented in this table are separated into "tested" and "reported". "Tested" fabrics were examined in the Fire Technology Division's laboratories. "Reported" fabrics were not tested at NBS and information regarding fiber content and construction was obtained from reports of the incident.

$\mathrm{b}_{\text {Two of }}$ the cotton robes and the acetate robe were quilted with a polyester middle layer and acetate inner layer.

$\mathrm{C}_{\mathrm{F} 1 \mathrm{annelette}}$ construction is included in this category.

All but three garments (1 pajama, 1 nightgown, 1 robe) were found, from tests or reports, to be cotton; it should be remembered, however, that as of 1970 cotton and cotton blends held over 70 percent of the market for sleepwear sizes 7-14 [5]. Flannel was the most common construction of the sleepwear that was tested; two-thirds (22) 
of the pajamas and three-fourths (17) of the nightgowns were cotton flannel. Plain cotton was the only other significantly represented fabric accounting for 23 percent of the tested pajamas and 18 percent of the tested nightgowns.

Fabric weight determinations were made for 55 fabric remnants that were of sufficient size to test. Table 9 shows the distribution of weights for pajama, nightgown and robe fabrics tested. Pajama and nightgown weights are clustered around $3.5-4.0 \mathrm{oz} / \mathrm{sq} . \mathrm{yd}$. and almost all were under $4.5 \mathrm{oz} . / \mathrm{sq} . y d$.

'Table 9. Fabric Weights of First-to-Ignite Sleepwear Items For the 6-12 Age Group

\begin{tabular}{ccccc}
\hline $\begin{array}{c}\text { Weight } \\
\text { (oz./sq. yd.) }\end{array}$ & Pajamas & Nightgowns & Robes & $\begin{array}{c}\text { All } \\
\text { Sleepwear }\end{array}$ \\
\hline Less than 2.6 & 3 & - & - & 3 \\
$2.6-3.0$ & 4 & 5 & - & 9 \\
$3.1-3.5$ & 6 & 3 & - & 9 \\
$3.6-4.0$ & 10 & 10 & 1 & 21 \\
$4.1-4.5$ & 5 & 2 & 1 & 8 \\
Greater than 4.5 & 1 & 2 & 2 & 5 \\
\hline
\end{tabular}

\section{FINDINGS FROM OTHER SOURCES}

Additional independent information from Shriners Burns Institute [6] and the National Burn Information Exchange (NBIE) [7] provide further evidence of the hazard facing children in the 6-12 age group. The Burns Institute compiled data on children age 16 or younger admitted to their hospital during the period March 1966 to December 31, 1970. The number of clothing ignitions (165) for the 6-12 age group slightly outnumbered those (153) for the $0-5$ age group as can be seen in table 10. Eighty-nine percent of the ignitions involved children age 12 or younger.

From reports, by 324 patients, of specific garment items ignited, 76 of 539 garments listed were sleepwear. As in the FFACTS data, girls' sleepwear was more frequently involved than boys'. Out of 279 girls' garments, 60 (21.5 percent) of the items were sleepwear. This is almost four times the 16 sleepwear items reported for boys. Table 11 details these figures. Note that the garment data from Shriners include all items involved in the incidents reported, whereas the FFACTS data (tables 1-9) include only those items first to ignite. Although table 11 indicates a relatively high involvement for underwear items (22 percent of all items involved), the FFACTS data in table 1 show that underwear was first to ignite in only 6 percent of the 995 garment incidents reported. Shirts and sleepwear, on the 
other hand, show a substantial involvement in both the FFACTS data and Shriners data since they are often the first items ignited in fire incidents (table 1 ).

Table 10. Frequency of Clothing Ignition Acute Admissions (SBI) ${ }^{a}$

\begin{tabular}{cccc}
\hline \multirow{2}{*}{ Age } & \multicolumn{2}{c}{ Number of } & \multicolumn{2}{c}{ Clothing } & \multicolumn{2}{c}{ Ignitions } \\
\cline { 2 - 4 } & Male & Female & Tota1 \\
\hline $0-1$ & 1 & 1 & 2 \\
$1-2$ & 4 & 5 & 9 \\
$2-3$ & 10 & 12 & 22 \\
$3-4$ & 15 & 15 & 30 \\
$4-5$ & 14 & 29 & 43 \\
$5-6$ & 18 & 29 & 47 \\
$6-7$ & 12 & 18 & 30 \\
$7-8$ & 11 & 12 & 23 \\
$8-9$ & 16 & 14 & 30 \\
$9-10$ & 18 & 13 & 31 \\
$10-11$ & 14 & 6 & 20 \\
$11-12$ & 10 & 10 & 20 \\
$12-13$ & 10 & 1 & 11 \\
$13-14$ & 9 & 6 & 15 \\
$14-15$ & 12 & 3 & 15 \\
$15-16$ & 6 & 3 & 9 \\
& & & \\
Total & 180 & 177 & 357 \\
\hline Source: & Shriners & Burns & Institute [6].
\end{tabular}

Table 11. Frequency of Specific Garment Item Ignition For Children Ages $0-16$ (SBI) $^{a}$

\begin{tabular}{l|cc|cc|cc}
\hline \multirow{2}{*}{$\begin{array}{c}\text { Garment } \\
\text { Item }\end{array}$} & \multicolumn{2}{|c|}{ Males } & \multicolumn{2}{c|}{ Females } & \multicolumn{2}{c}{ Tota1 } \\
\cline { 2 - 7 } & Number & Percent & Number Percent & Number Percent \\
\hline Shirts/BIouses & 79 & 30.4 & 24 & 8.6 & 103 & 19.1 \\
Trousers . . . & 64 & 24.6 & - & - & 64 & 11.9 \\
Underwear. . . & 50 & 19.2 & 70 & 25.1 & 120 & 22.2 \\
Sleepwear. . . & 16 & 6.2 & 60 & 21.5 & 76 & 14.1 \\
Dresses/Skirts & - & - & 86 & 30.8 & 86 & 16.0 \\
Miscellaneous. & 51 & 19.6 & 39 & 14.0 & 90 & 16.7 \\
& & & & & & \\
Total. . . & 260 & 100.0 & 279 & 100.0 & 539 & 100.0 \\
\hline
\end{tabular}

a Source: Shriners Burns Institute [6]. 
Table 12 shows the distribution of 3,982 clothing items ignited in 3,553 NBIE cases from civilian hospitals. These data again include a11 clothing ignited, not just the garments first to ignite. Fifteen percent of the garments in the 6-14 age group were sleepwear items compared to 16 percent for the 0-5 age group. The number of sleepwear items ignited for the $0-5$ and 6-14 groups combined represents 46 percent of all the sleepwear items involved in these cases.

Table 12. Distribution of Clothing Ignited by Age Group ${ }^{a}$ (NBIE)

\begin{tabular}{|c|c|c|c|c|c|c|c|c|}
\hline \multirow{3}{*}{$\begin{array}{l}\text { Garment } \\
\text { Item }\end{array}$} & \multicolumn{6}{|c|}{ Ages of Persons Involved } & \multirow{2}{*}{\multicolumn{2}{|c|}{ Total }} \\
\hline & $0-5$ & Years & $6-14$ & Years & Over 14 & Years & & \\
\hline & Number & Percent & Number & Percent & Number & Percent & Number & Percent \\
\hline Shirt/Blouse & 135 & 20 & 261 & 28 & 716 & 30 & 1,112 & 28 \\
\hline Pants/Slacks. & 108 & 16 & 213 & 23 & 620 & 26 & 941 & 24 \\
\hline Dress/Skirt. & 158 & 24 & 148 & 16 & 143 & 6 & 449 & 11 \\
\hline Underwear. . & 84 & 13 & 93 & 10 & 263 & 11 & 440 & 11 \\
\hline Sleepwear. & 109 & 16 & 140 & 15 & 287 & 12 & 536 & 13 \\
\hline Sweater. & 9 & 1 & 9 & 1 & 48 & 2 & 66 & 2 \\
\hline Other Clothing & 49 & 7 & 55 & 6 & 264 & 11 & 368 & 9 \\
\hline Non-Clothing : & 13 & 2 & 9 & 1 & 48 & 2 & 70 & 2 \\
\hline Total. & 665 & 99 & 928 & 100 & 2,389 & 100 & 3,982 & 100 \\
\hline
\end{tabular}

a Derived from NBIE data in [7].

\section{CONCLUSIONS}

The data presented in the preceding sections indicate that the flammability of sleepwear is a hazard to children of ages 6 through 12. In the FFACTS data base as a whole, sleepwear is the fabric item which is most frequently first to ignite. Almost one-fourth of these sleepwear incidents involved children in the 6-12 age group, while another one-fourth involved children under age 6 . Thus, children under age 13 represent half of the persons involved in first-to-ignite sleepwear incidents in FFACTS. High susceptibility to sleepwear ignitions is not limited to children under age 6 , for whom a standard already exists, but appears to extend uniformly through age 12. Data from Shriners Burns Institute and NBIE corroborate the relatively equal involvement of the $0-5$ and $6-12$ age groups in garment fires (tables 10, 12).

Females 6-12 years old were much more vulnerable than males of the same age to ignitions of sleepwear. Sixty-one of 77 children 6-12 years old involved in first-to-ignite sleepwear incidents were female (table 2). This represents a much higher female involvement than in the $0-5$ age group. It also is the beginning of a pattern which is evidenced in all higher age groups - the complete dominance of females 
in fabric fires started by ignition of sleepwear. The Shriners Burns Institute study provides additional evidence of the high ratio of females-to-males involved in sleepwear ignitions (table 11).

Market data on children's sleepwear help place the FFACTS data in perspective. According to a 1972 study [8] by the American Apparel Manufacturers' Association (AAMA), girls and boys shared equally the size 7-14 (ages 6-12) sleepwear market. Girls in this age group therefore seem to face a much greater risk than boys in the same age group.

Kitchen ranges and nightgowns appear to be the two major factors that contributed to the relatively high female involvement in the 6-12 age group. Kitchen ranges were responsible for 38 of the 77 sleepwear ignitions in this group and females were involved in 32 of the 38 (table 5). If it is true that girls spend more time in the kitchen than boys, and accordingly come in contact with kitchen ranges more frequently, then this would account, in part, for the low representation of males in incidents stemming from sleepwear ignition.

From the FFACTS data it can be seen that kitchen ranges were the predominant source of ignition for girls' pajamas in the 6-12 age group. Twenty-two of 27 girls' pajamas were ignited by ranges. Kitchen range ignitions of girls' nightgowns, however, represent a much smaller proportion of nightgown ignitions. Thirty-one of the 77 first-to-ignite sleepwear items were nightgowns, all but one worn by females; yet, only 9 of the girls' nightgowns were ignited by kitchen ranges.

There are several possible reasons for the apparent differences in the interactions of kitchen ranges with pajamas and nightgowns. A primary factor is garment construction and its relationship to various ignition sources and activity patterns of persons involved in these incidents. Pajamas are generally in two pieces - a loose shirt top and a pants bottom - while nightgowns are one piece and by nature loose fitting and flowing. In ignitions of these garments by kitchen ranges, there are four distinct areas that are particularly vulnerable: (1) the cuffs and sleeves of both pajamas and nightgowns, (2) the pajama tops, (3) the midsection of nightgowns and (4) the hemmed edge at the bottoms of nightgowns. Range ignition of the hemmed bottoms of nightgowns most frequently involved 0-5 year olds who, because of their limited height and reach, often climbed up on the range top. Children over age 5 usually are taller than the range and are able to reach for what they want without climbing, although there are a few cases of climbing in the 6-12 age group. This factor therefore appears to be only a minor problem in the 6-12 age group; the hemmed lower edges of pajamas and nightgowns were not ignited frequently by ranges. 
Since the average heights of 6-12 year olds range from under 4 feet to 5 feet $[9,10]$ and kitchen ranges are approximately 3 feet high, many children in this group are tall enough to see and reach things on or above the range. Clearly, in reaching across or leaning against a kitchen range children in the 6-12 age group expose abovethe-waist sections of their garments to ignition. The minimal clearance between a child's extended arm and a range burner presents a hazard to the cuffs and sleeves of nightgowns as well as pajamas. Pajama tops, though, may be more vulnerable to ignition than the top portion of nightgowns since the top of a pajama is loose and able to drape over a burner. A nightgown clings closer to the upper part of the body due to the weight of the material in the lower portion of the garment. This limits the opportunity for the nightgown top to drape over a burner especially considering the 4-5 feet heights of the children involved. In this way, garment construction may partially explain the predominance of girls' pajamas in kitchen range incidents.

Market data from the AAMA study [8] show that pajamas represent 60 percent and nightgowns 40 percent of the girls' sleepwear market for sizes 7-14. Therefore, one might expect 50 percent more pajama ignitions than nightgown ignitions if pajamas and nightgowns were equally hazardous in the same situations. This may be partially responsible for the ratio (22 to 9) of girls' pajamas to nightgowns in kitchen range ignitions assuming the garments to have relatively equal hazards above the waist. However, these market data cannot explain the fact that, when all ignition sources are considered, approximately equal numbers of females' pajamas and nightgowns are ignited. For ignition sources other than ranges (matches, lighters, heaters and open fires), the construction of nightgowns makes them more prone than pajamas to ignition below the waist. The flowing, loose nature of nightgowns inadvertently exposes the hems to heat sources such as space heaters and fireplaces which pajama bottoms would not ordinarily come in contact with. Ignition sources other than kitchen ranges ignited 21 girls' nightgowns and only 5 girls' pajamas in FFACTS incidents involving the 6-12 age group.

An interesting characteristic of sleepwear fires involving 6-12 year olds as well as all other age groups is the almost complete absence of flammable liquids in the ignition sequences. Contamination by flammable liquids does not appear to be a significant problem in sleepwear ignitions.

Finally but most important are the injuries suffered by these children. Of 77 children ages 6-12 whose sleepwear was first to ignite in FFACTS incidents, 52 were hospitalized and 5 died. No one was known to have escaped injury. These children probably would not have been severely burned had the sleepwear they were wearing been flame retardant. But no conclusions could be drawn as to the 
relationships between the severity of the injury and the fabric weight of the sleepwear, since virtually all fabrics were within a narrow weight range.

\section{RECOMMENDATIONS}

Since the present children's sleepwear flammability standard, DOC FF3-71, applies to sizes $0-6 \mathrm{X}$ on $1 \mathrm{y}$, children over age 5 are not afforded the protection of the standard. Yet, children between the ages of 6 and 12 face a flammability hazard similar to that of children under age 5 . It is therefore recommended that a new flammability standard be issued to cover sleepwear worn by the 6-12 age group, or sizes 7 through 14 .

Furthermore, it is also suggested that the role of kitchen ranges in garment fires be thoroughly studied in light of the large number of fire incidents apparently started by direct ignition from range burners. Subsequently, some attention should be given to possible remedial action that would diminish the ignition hazards resulting from the interaction of ranges with garments and children.

\section{GLOSSARY}

Contaminated item: A fabric item soaked with or in contact with flammable liquids at the time of ignition.

Incident: A single ignition event originating from a single heat source and involving (possibly via an intermediary material) one or more fabrics or fabric products and any and all persons directly involved in the resulting fire.

Intermediary material: Any non-fabric material, such as wood, gasoline or natural gas, which acts as a link in the ignition sequence transferring heat from an initial source of ignition to fabric items which subsequently become involved in the fire.

Item: Any fabric, fabric product or related material intended or promoted for use.

Person involved: Any individual who initiates a fabric fire incident or who is injured in such an incident or who is in some way directly involved in an incident.

Sleepwear: Any product of wearing apparel such as a nightgown, pajama, or similar or related item, such as a robe, intended to be worn primarily for sleeping or activities related to sleeping. Diapers and underwear are excluded from this definition. 
[1] The Standard For the Flammability of Children's Sleepwear, DOC FF3-71, Federal Register, Vol. 37, No. 141 (July 21, 1972), 14624-14632 (Revised).

[2] Children's Sleepwear, Notice of Finding That Flammability Standard May Be Needed and Institution of Proceedings, Federal Register, Vo1. 37, No. 116 (June 15, 1972), 11896-11897.

[3] The Flammable Fabrics Act, 81 Stat. 568, 15 U.S.C. 1191, as amended and revised Dec. 14, 1967.

[4] U.S. Bureau of the Census, 1970 Census of Population, United States, General Population Characteristics, Advance Report, PC(V2)-1 (Feb. 1971).

[5] National Cotton Council of America, Cotton Counts Its Customers, 1965-1971, Special Edition (Feb. 1973), 26,38.

[6] Shriners Burns Institute, Study of Children Admitted to S. B. I., Whose Injuries Resulted From Ignition and Burning of Clothing, unpublished report.

[7] U.S. Department of Health, Education and Welfare, Third Annual Report to the President and the Congress, Studies of Deaths, Injuries and Economic Losses Resulting From Accidental Burning of Products, Fabrics, or Related Materials (1971), 115.

[8] American Apparel Manufacturers' Association, Cost Consequences to the Consumer Regarding Certain Aspects of a Children's Sleepwear Standard, Sizes 7 to 14, Report to Acting Assistant Secretary of Commerce For Science and Technology (Dec. 15, 1972).

[9] U.S. Department of Health, Education and Welfare, Vital and Health Statistics Series 11, No. 104, Height and Weight of Children - United States.

[10] U.S. Department of Health, Education and Welfare, Vital and Health Statistics Series 11, No. 124, Height and Weight of Youths 12-17 Years - United States. 
|FORM NBS-114A (1-71)

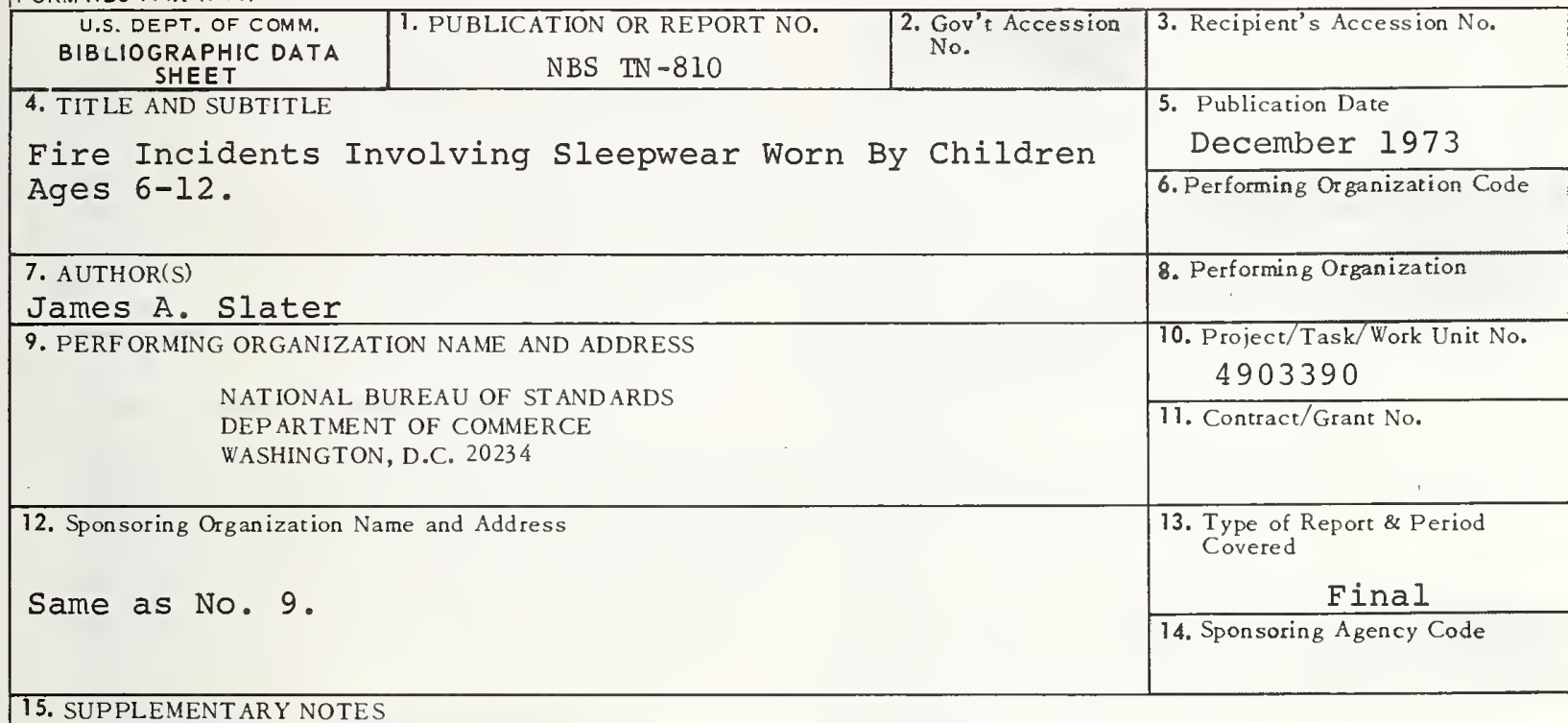

16. ABSTRACT (A 200-word or less factual summary of most significant information. If document includes a significant bibliography or literarure survey, mention it here.)

Sleepwear was the first fabric item ignited more frequently than any other item in over 1,900 fire incidents reported to the National Bureau of Standards Flammable Fabrics Accident Case and Testing System (FFACTS). Information acquired since promulgation of the current sleepwear flammability standard protecting children of ages 0-5 indicates a problem of comparable magnitude exists for children of ages 6-12. Of 316 incidents involving non-contaminated sleepwear that was first to ignite, about onefourth involved children 0-5 years old and one-fourth involved children 6-12 years old. For the 6-12 group, sleepwear ignited first more often than all other garment items combined. Females outnumbered males 4-to-1 in the 6-12 group, due mostly to the involvement of nightgowns and kitchen ranges, the most common ignition source for this age group. Five of the 6-12 year old children died and 52 of 74 victims were hospitalized. Almost all of the first-to-ignite sleepwear in this group was cotton. Data from Shriners Burns Institute and the National Burn Information Exchange provide further evidence of the involvement of children ages 6-12 in garment fires. It is recommended that a new standard be issued covering sleepwear sizes 7 through 14 to effectively protect 6-12 year old children.

17. KEY WORDS (Alphabetical order, separated by semicolons)

Accidents; burns; children; clothing fires; deaths; FFACTS; fire; flammable fabrics; injury; sleepwear; standards; statistics.

\begin{tabular}{|c|c|c|}
\hline $\begin{array}{l}\text { 18. AVAILABILITY STATEMENT } \\
\text { XXUNL IMITED. }\end{array}$ & $\begin{array}{l}\text { 19. SECURITY CLASS } \\
\text { (THIS REPORT) } \\
\text { UNCL ASSIF IED }\end{array}$ & $\begin{array}{l}\text { 21. NO. OF PAGES } \\
23\end{array}$ \\
\hline $\begin{array}{l}\square \text { FOR OFFICIAL DISTRIBUTION. DO NOT RELEASE } \\
\text { TO NTIS. }\end{array}$ & $\begin{array}{l}\text { 20. SECUR ITY CLASS } \\
\text { (THIS PAGE) } \\
\text { UNCL ASSIFIED }\end{array}$ & $\begin{array}{r}\text { 22. Price } \\
\$ .50\end{array}$ \\
\hline
\end{tabular}



PERIODICALS

JOURNAL OF RESËARCH reports National Bureau of Standards research and development in physics, mathematics, and chemistry. Comprehensive scientific papers give complete details of the work, including laboratory data, experimental procedures, and theoretical and mathematical analyses. Illustrated with photographs, drawings, and charts. Includes listings of other NBS papers as issued.

Published in two sections, available separately:

\section{- Physics and Chemistry (Section A)}

Papers of interest primarily to scientists working in these fields. This section covers a broad range of physical and chemical research, with major emphasis on standards of physical measurement, fundamental constants, and properties of matter. Issued six times a year. Annual subscription: Domestic, $\$ 17.00$; Foreign, $\$ 21.25$.

\section{- Mathematical Sciences (Section B)}

Studies and compilations designed mainly for the mathematician and theoretical physicist. Topics in mathematical statistics, theory of experiment design, numerical analysis, theoretical physics and chemistry, logical design and programming of computers and computer systems. Short numerical tables. Issued quarterly. Annual subscription: Domestic, $\$ 9.00$; Foreign, $\$ 11.25$.

\section{DIMENSIONS, NBS}

The best single source of information concerning the Bureau's measurement, research, developmental, cooperative, and publication activities, this monthly publication is designed for the layman and also for the industry-oriented individual whose daily work involves intimate contact with science and technology - for engineers, chemists, physicists, research managers, product-development managers, and company executives. Annual subscription: Domestic, $\$ 6.50$; Foreign, $\$ 8.25$.

\section{MOMPERIODICALS}

Applied Mathematics Series. Mathematical tables, manuals, and studies.

Building Science Series. Research results, test methods, and performance criteria of building materials, components, systems, and structures.

Handbooks. Recommended codes of engineering and industrial practice (including safety codes) developed in cooperation with interested industries, professional organizations, and regulatory bodies.

Special Publications. Proceedings of NBS conferences, bibliographies, annual reports, wall charts, pamphlets, etc.

Monographs. Major contributions to the technical literature on various subjects related to the Bureau's scientific and technical activities.

National Standard Reference Data Series. NSRDS provides quantitative data on the physical and chemical properties of materials, compiled from the world's literature and critically evaluated.

Product Standards. Provide requirements for sizes, types, quality, and methods for testing various industrial products. These standards are developed cooperatively with interested Government and industry groups and provide the basis for common understanding of product characteristics for both buyers and sellers. Their use is voluntary.

Technical Notes. This series consists of communications and reports (covering both other-agency and NBS-sponsored work) of limited or transitory interest.

Federal Information Processing Standards Publications. This series is the official publication within the Federal Government for information on standards adopted and promulgated under the Public Law 89-306, and Bureau of the Budget Circular A-86 entitled, Standardizatian of Data Elements and Codes in Data Systems.

Consumer Information Series. Practical information, based on NBS research and experience, covering areas of interest to the consumer. Easily understandable language and illustrations provide useful background knowledge for shopping in today's technological marketplace.

\section{BIBLIOGRAPHIC SUBSCRIPTION SERVICES}

The following current-awareness and literature-survey bibliographies are issued periodically by the Bureau :

Cryogenic Data Center Current Awareness Service (Publications and Reports of Interest in Cryogenics). A literature survey issued weekly. Annual subscription: Domestic, $\$ 20.00$; foreign, $\$ 25.00$.

Liquefied Natural Gas. A literature survey issued quarterly. Annual subscription: $\$ 20.00$.

Superconducting Devices and Materials. A literature survey issued quarterly. Annual subscription: $\$ 20.00$. Send subscription orders and remittances for the preceding bibliographic services to the U.S. Department of Commerce, National Technical Information Service, Springfield, Va. 22151.

Electromagnetic Metrology Current Awareness Service (Abstracts of Selected Articles on Measurement Techniques and Standards of Electromagnetic Quantities from D-C to Millimeter-Wave Frequencies). Issued monthly. Annual subscription: $\$ 100.00$ (Special rates for multi-subscriptions). Send subscription order and remittance to the Electromagnetic Metrology Information Center, Electromagnetics Division, National Bureau of Standards, Boulder, Colo. 80302.

Order NBS publications (except Bibliographic Subscription Services) from: Superintendent of Documents, Government Printing Office, Washington, D.C. 20402. 
U.S. DEPARTMENT OF COMMERCE

National Bureau of Standards

Washington, D.C. 20234

OFFICIAL BUSINESS

POSTAGE AND FEES PAID

U.S. DEPARTMENT OF CDMMERCE

$C O M=215$

Penalty for Private Use, $\$ 300$

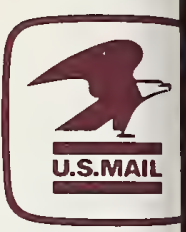



- 
